\title{
Tool Wear of Aluminum-Chromium Based Coated Cemented Carbide in Cutting Hardened Sintered Steel
}

\author{
Tadahiro Wada, Mitsunori Ozaki, Hiroyuki Hanyu, and Kinya Kawase
}

\begin{abstract}
Tool life in turning sintered steels is shorter than that in turning melted steels such as carbon steels. In order to identify an effective tool material for cutting hardened sintered steel, tool wear was experimentally investigated. Hardened sintered steel was turned with two kinds of PVD coated cemented carbide tools. The coating films used were ( $\mathrm{Ti}, \mathrm{Al}) \mathrm{N}$ and $(\mathrm{Al}, \mathrm{Cr}) \mathrm{N}$. The main results obtained are as follows: (1) The wear progress of the $(\mathrm{Al}, \mathrm{Cr}) \mathrm{N}$ coated cemented carbide tool was slower than that of the $(\mathrm{Ti}, \mathrm{Al}) \mathrm{N}$ coated cemented carbide tool. (2) Because the $(\mathrm{Al}, \mathrm{Cr}) \mathrm{N}$ coating film exhibited both higher hardness and higher oxidation temperature, the wear progress of the (Al,Cr)N coated cemented carbide became slower. (3) In cutting hardened sintered steel with $(\mathrm{Al}, \mathrm{Cr}) \mathrm{N}$ coated cemented carbide tool, there was little influence of the cutting speed on the tool wear within the range of the cutting speed from $0.5 \mathrm{~m} / \mathrm{s}$ to $1.0 \mathrm{~m} / \mathrm{s}$.
\end{abstract}

Index Terms-Turning, hardened sintered steel, physical vapor deposition coating film, $(\mathrm{Al}, \mathrm{Cr}) \mathrm{N},(\mathrm{Ti}, \mathrm{Al}) \mathrm{N}$.

\section{INTRODUCTION}

A machine part having a complicated shape can be mass-produced accurately by powder metallurgy. A diffusion alloyed powder or a completely alloyed powder is usually used as an alloyed powder for the sintered steel. The compressibility of the diffusion alloyed powder is better than that of the completely alloyed powder. After the sintering, the sintered material is quenched and tempered to improve the mechanical properties and wear-resistance. For dimensional accuracy, it is often necessary for the sintered steel machine parts to be machined by the metal removal process [1]. As the sintered machine parts are often cut at high cutting speed for mass-production, the tool materials must have good wear resistance. The polycrystalline cubic boron nitride compact (cBN) seems to be an effective tool material because it has good heat resistance and wear resistance [2]. However, in milling, a major tool failure of $\mathrm{cBN}$ readily occurs by fracture because $\mathrm{cBN}$ has poor fracture toughness. Coated cemented carbide tools, which have good fracture toughness and wear resistance, seem to be effective tool materials. TiN, $\operatorname{Ti}(\mathrm{C}, \mathrm{N})$ and $(\mathrm{Ti}, \mathrm{Al}) \mathrm{N}$ are generally used for the coating film. So, there are many studies on the wear-resistance of these coating layers. Although there are some studies on the tool wear characteristics of the PVD coated cemented carbide tools in

Manuscript received June 15, 2013; revised July 30, 2013.

Tadahiro Wada and Mitsunori Ozaki are with the Nara National College of Technology, 22 Yata-cho, Yamatokoriyama 639-1080, Japan (e-mail: wada@mech.nara-k.ac.jp).

Mitsunori Ozaki is with the Nara National College of Technology.

Hiroyuki Hanyu is with the OSG Corporation.

Kinya Kawase is with the Diamet Corporation. the cutting of the hardened steel [3] or the sintered steel [4], there are few studies on tool wear in the cutting of the hardened sintered steel.

An aluminum-chromium based coating film, namely $(\mathrm{Al}, \mathrm{Cr}) \mathrm{N}$ coating film, which exhibits a superior critical scratch load, has been developed. The aluminum-chromium based coated tool was evaluated through the machining of sintered steel, and showed greatly improved performance [5]. However, the effectiveness of the aluminum-chromium coating film is unclear when cutting hardened sintered steel.

In this study, to clarify the effectiveness of aluminum-chromium coating film for cutting hardened sintered steel, tool wear was experimentally investigated. The hardened sintered steel was turned with an aluminum-chromium based coated tool according to a physical vapor deposition (PVD) method. Moreover, the tool wear of the aluminum-chromium based coated item was compared with that of $(\mathrm{Ti}, \mathrm{Al}) \mathrm{N}$ coated tools.

\section{EXPERIMENT DETAILS}

The work material used was hardened sintered steel from diffusion alloyed powder. This material had a density of 7.1 $\mathrm{Mg} / \mathrm{m}^{3}$, and many pores were observed when examining the structure by microscope. The chemical composition and the mechanical properties of the hardened sintered steel are shown in Table I. That is, the hardened sintered steel had a hardness of 339 HBS. The cutting conditions are shown in Table II. The tool material of the substrate was cemented carbide, and two types of PVD-coated cemented carbide were used. Namely, the coating films used were $(\mathrm{Ti}, \mathrm{Al}) \mathrm{N}$ and ( $\mathrm{Al}, \mathrm{Cr}) \mathrm{N}$ coating film. $(\mathrm{Al}, \mathrm{Cr}) \mathrm{N}$ is a new type of coating film. The configurations of tool inserts were TNGA160408. The insert was attached on the tool holder MTGNR2525M16. In this case, the tool geometry was $(-6,-6,6,6,30,0,0.8 \mathrm{~mm})$.

The turning tests were carried out on a precision lathe (Type ST5, SHOUN MACHINE TOOL Co., Ltd.) with an added variable-speed drive. The driving power of this lathe is $7.5 / 11 \mathrm{~kW}$ and the maximum rotational speed is $2500 \mathrm{~min}^{-1}$. The tool wear of the two kinds of turning insert was investigated.

TABLE I: CHEMICAL COMPOSITION AND PROPERTIES OF HARDENED SINTERED STEEL

\begin{tabular}{ccccc}
\hline \hline \multicolumn{5}{c}{ Chemical composition (mass \%) } \\
\hline $\mathrm{C}$ & $\mathrm{Cu}$ & $\mathrm{Ni}$ & $\mathrm{Mo}$ & $\mathrm{Fe}$ \\
\hline $0.3-0.7$ & $1-2$ & $3-5$ & $0.2-0.8$ & Bal. \\
\hline \hline \multicolumn{5}{c}{ Properties } \\
\hline \multicolumn{5}{c}{ Hardness } \\
\hline 339 HBS $(5 \mathrm{~mm} / 7350 \mathrm{~N})$ & $7.1 \mathrm{Mg} / \mathrm{m}^{3}$ \\
\hline \hline
\end{tabular}


TABLE II: CUTTING CONDITIONS

\begin{tabular}{ll}
\hline \hline Cutting speed & $\mathrm{V}=0.50,0.75,1.00[\mathrm{~m} / \mathrm{s}]$ \\
\hline \hline Feed rate & $\mathrm{S}=0.05[\mathrm{~mm} / \mathrm{rev}]$ \\
\hline \hline Depth of cut & $\mathrm{a}=0.1[\mathrm{~mm}]$ \\
\hline \hline Tool geometry & $(-6,-6,6,6,30,0,0.8 \mathrm{~mm})$ \\
\hline \hline \multirow{2}{*}{ Tool insert } & $\begin{array}{l}\text { Substrate: Cemented carbide ISO K10 } \\
\text { Coating film: }(\mathrm{Ti}, \mathrm{Al}) \mathrm{N},(\mathrm{Al}, \mathrm{Cr}) \mathrm{N}\end{array}$ \\
\hline \hline Cutting method & Dry \\
\hline \hline
\end{tabular}

\section{RESULTS AND DISCUSSION}

The hardened sintered steel was turned with two kinds of coated cemented carbide tool at a feed rate of $0.05 \mathrm{~mm} / \mathrm{rev}$ and a depth of cut of $0.1 \mathrm{~mm}$. Fig. 1 shows the SEM observation of the tool wear. Fig.1 (a) and (b) show the case of the $(\mathrm{Ti}, \mathrm{Al}) \mathrm{N}$ coated and the $(\mathrm{Al}, \mathrm{Cr}) \mathrm{N}$ coated tool at a cutting speed of $1.00 \mathrm{~m} / \mathrm{s}$, respectively. In the case of the (Ti,Al)N coated tool shown in Fig. 1 (a), a crater is found on the rake face along the cutting edge, and adhesion on both the rake and flank faces is not remarkable either. Also, the flaking of the coating layer is not remarkable. In the case of the $(\mathrm{Al}, \mathrm{Cr}) \mathrm{N}$ coated tool shown in Fig. 1 (b), there is no remarkable crater on the rake face. And adhesion on the flank face is found, while the flaking of the coating layer is also unremarkable.

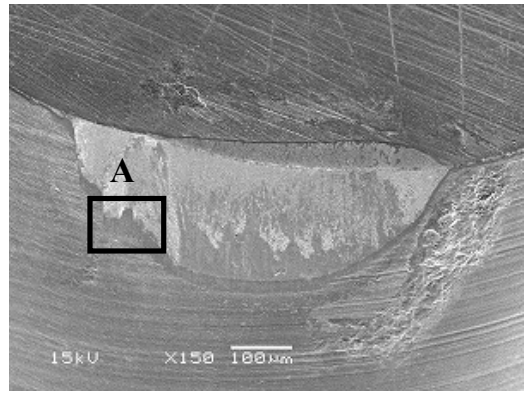

(a) $(\mathrm{Ti}, \mathrm{Al}) \mathrm{N}, \mathrm{L}=1.9 \mathrm{~km}$

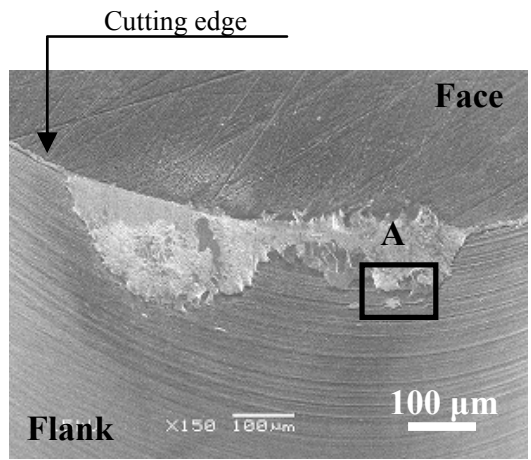

(b) $(\mathrm{Al}, \mathrm{Cr}) \mathrm{N}, \mathrm{L}=4.5 \mathrm{~km}$

Fig. 1. Tool wear at cutting speed of $1.00 \mathrm{~m} / \mathrm{s}$, feed rate of $0.05 \mathrm{~mm} / \mathrm{rev}$, depth of cut of $0.1 \mathrm{~mm}$ and cutting method of dry cutting. (a) $(\mathrm{Ti}, \mathrm{Al}) \mathrm{N}$ coated tool and (b) $(\mathrm{Al}, \mathrm{Cr}) \mathrm{N}$ coated tool.

Following these experiments, it emerged that the main tool failure for two kinds of coated tools in cutting hardened sintered steel was the flank wear within a maximum value of the flank wear width of about $0.2 \mathrm{~mm}$. Therefore, the maximum value of the flank wear width (VBmax) was measured by microscope.

Fig. 2 shows the wear progress in cutting two kinds of coated tools at a cutting speed of $1.00 \mathrm{~m} / \mathrm{s}$. The wear progress of the $(\mathrm{Al}, \mathrm{Cr}) \mathrm{N}$ coated tool is slower than that of the $(\mathrm{Ti}, \mathrm{Al}) \mathrm{N}$ coated tool. As mentioned above, the $(\mathrm{Al}, \mathrm{Cr}) \mathrm{N}$ coated cemented carbide is an effective tool material in cutting hardened sintered steel, so Scanning Electron Microscopy (SEM) observation and Energy Dispersive X-ray Spectrometer (EDS) analysis were carried out on the worn surface.

Fig. 3 shows the SEM observation and EDS mapping analysis on the worn surface of the $(\mathrm{Ti}, \mathrm{Al}) \mathrm{N}$ coated tool and the (Al, Cr)N coated tool. Fig.3 (a) shows the details of "A" shown in Fig. 1. Fig. 3 (b) shows the EDS analysis in the case of the oxygen $(\mathrm{O})$ mapping on the cutting part shown in Fig. 1. First, as compared with the worn surface of (Ti,Al)N coating film indicated by "B" shown in Fig. 3 i(a) and that of $(\mathrm{Al}, \mathrm{Cr}) \mathrm{N}$ coating film indicated by "B" shown in Fig. 3 ii(a), many striae scratched by a hard material are remarkably found on the worn surface in the case of both the $(\mathrm{Ti}, \mathrm{Al}) \mathrm{N}$ and the $(\mathrm{Al}, \mathrm{Cr}) \mathrm{N}$ coating film. Therefore, the main wear mechanism of both the $(\mathrm{Ti}, \mathrm{Al}) \mathrm{N}$ and the $(\mathrm{Al}, \mathrm{Cr}) \mathrm{N}$ coating film is considered to be abrasive wear. In the case of abrasive wear, the wear-resistance of the coating film often depends on the hardness of the coating film. That is, a coating film with higher hardness has good wear-resistance. So, the characteristics of the coating films were investigated. The results are shown in Table III. The thickness of coating of (Al,Cr)N film is $3 \mu \mathrm{m}$, which is the same as that of $(\mathrm{Ti}, \mathrm{Al}) \mathrm{N}$ film. The $(\mathrm{Al}, \mathrm{Cr}) \mathrm{N}$ coating is harder than the $(\mathrm{Ti}, \mathrm{Al}) \mathrm{N}$ coating because the wear progress of $(\mathrm{Al}, \mathrm{Cr}) \mathrm{N}$ is considered to be slower than that of $(\mathrm{Ti}, \mathrm{Al}) \mathrm{N}$.

\begin{tabular}{ccccc}
\hline \multicolumn{5}{c}{ TABLE III: PROPERTIES OF COATING FILMS } \\
\hline $\begin{array}{c}\text { Coating } \\
\text { film }\end{array}$ & $\begin{array}{c}\text { Thickness } \\
{[\mu \mathrm{m}]}\end{array}$ & $\begin{array}{c}\text { Hardness } \\
{\left[\mathrm{HV}_{0.25 \mathrm{~N}}\right]}\end{array}$ & $\begin{array}{c}\text { Coefficient } \\
\text { of friction }\end{array}$ & $\begin{array}{c}\text { Oxidation } \\
\text { temperature } \\
{[\mathrm{K}]}\end{array}$ \\
\hline$(\mathrm{Ti}, \mathrm{Al}) \mathrm{N}$ & 3.0 & 2800 & 0.30 & 1123 \\
\hline$(\mathrm{Al}, \mathrm{Cr}) \mathrm{N}$ & 3.0 & 3100 & 0.25 & 1373 \\
\hline \hline
\end{tabular}

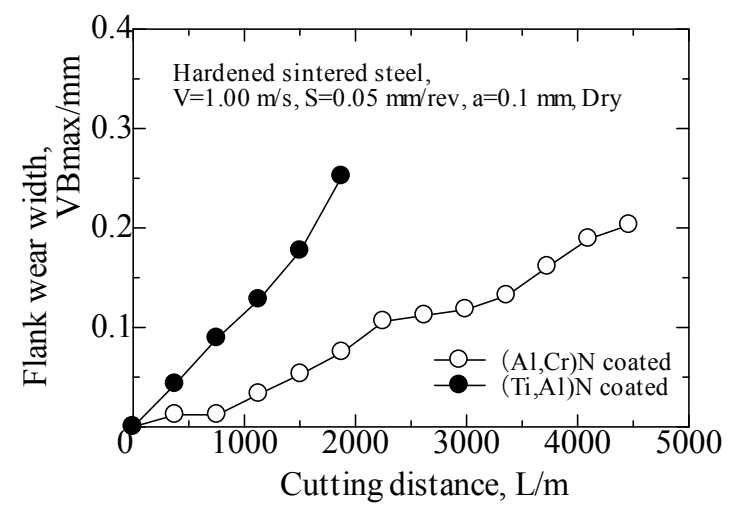

Fig. 2. Comparison of wear progress of the (Ar, Cr)N coated and (Ti,Al)N coated tool at cutting speed of $1.00 \mathrm{~m} / \mathrm{s}$, feed rate of $0.05 \mathrm{~mm} / \mathrm{rev}$, depth of cut of $0.1 \mathrm{~mm}$ and cutting method of dry cutting.

Second, as compared with the oxygen element on the worn surface of the (Ti,Al)N coating film shown in Fig. 3 i(b) and that of the $(\mathrm{Al}, \mathrm{Cr}) \mathrm{N}$ coating film shown in Fig. 3 ii(b), the oxygen element of the $(\mathrm{Al}, \mathrm{Cr}) \mathrm{N}$ coating film, which was turned at long cutting distance, is less than that of the (Ti,Al)N coating film. Therefore, the cutting temperature of the $(\mathrm{Al}, \mathrm{Cr}) \mathrm{N}$ coating film is considered to be lower than that of the $(\mathrm{Ti}, \mathrm{Al}) \mathrm{N}$ coating film, and the wear progress of the $(\mathrm{Al}, \mathrm{Cr}) \mathrm{N}$ is slower than that of the $(\mathrm{Ti}, \mathrm{Al}) \mathrm{N}$. One reason for the lower cutting temperature of the $(\mathrm{Al}, \mathrm{Cr}) \mathrm{N}$ coating film is as follows. 

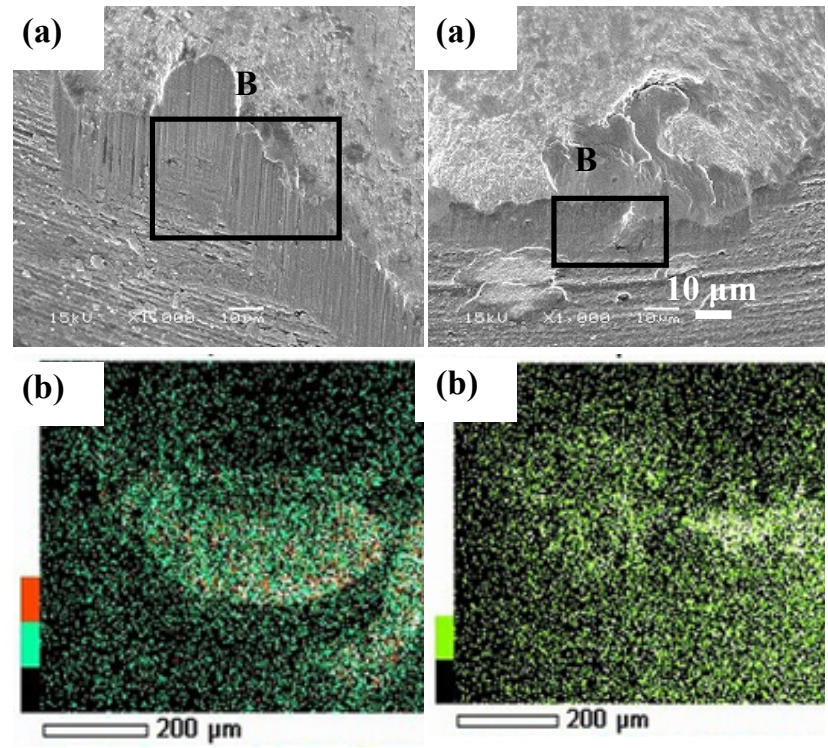

(i) $(\mathrm{Ti}, \mathrm{Al}) \mathrm{N}, \mathrm{L}=1.9 \mathrm{~km}$

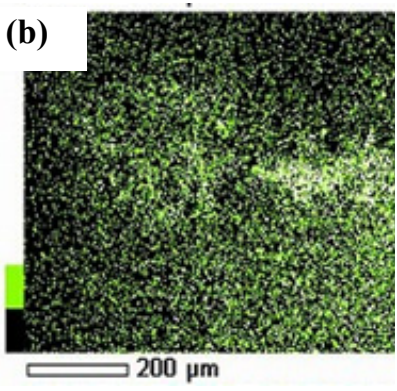

(ii) $(\mathrm{Al}, \mathrm{Cr}) \mathrm{N}, \mathrm{L}=4.5 \mathrm{~km}$

Fig. 3. SEM observation and EDS mapping analysis on the worn surface (i) $(\mathrm{Ti}, \mathrm{Al}) \mathrm{N}$ coated tool and (ii) $(\mathrm{Al}, \mathrm{Cr}) \mathrm{N}$ coated tool at cutting speed of 1.00 $\mathrm{m} / \mathrm{s}$, feed rate of $0.05 \mathrm{~mm} / \mathrm{rev}$, depth of cut of $0.1 \mathrm{~mm}$ and cutting method of dry cutting. (a) details of A shown in Fig. 1 and (b) EDS analysis of oxygen mapping shown in Fig. 1

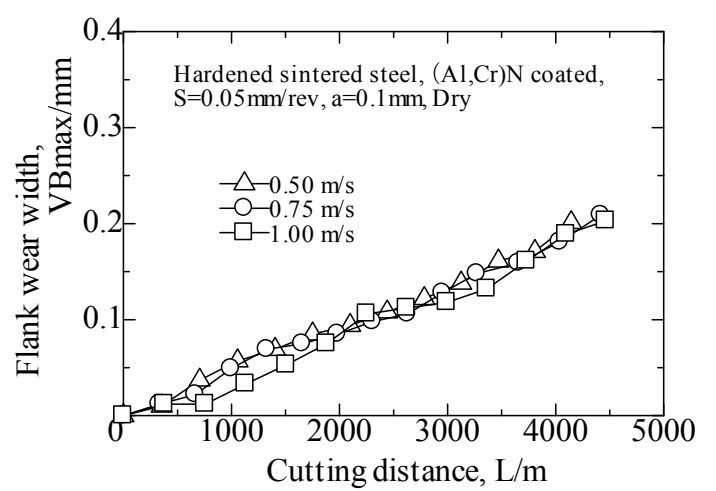

Fig. 4. Relation between cutting distance and flank wear width at various cutting speeds with $(\mathrm{Al}, \mathrm{Cr}) \mathrm{N}$ coated tool at a feed rate of $0.05 \mathrm{~mm} / \mathrm{rev}$, depth of cut of $0.1 \mathrm{~mm}$ and cutting method of dry cutting.

That is, the $(\mathrm{Al}, \mathrm{Cr}) \mathrm{N}$ coating film has a lower coefficient of friction as compared with the (Ti,Al)N coating film. Furthermore, the $(\mathrm{Al}, \mathrm{Cr}) \mathrm{N}$ coating film has a lower oxidation temperature as shown in Table III. This is considered to be the reason why there is less tool wear of the $(\mathrm{Al}, \mathrm{Cr}) \mathrm{N}$ coated tool.

As mentioned above, (Al,Cr)N was found to have superior properties for coating material compared to (Ti,Al)N in cutting hardened sintered steel.

In cutting hardened sintered steel at various cutting speeds, the wear progress was investigated at a feed rate of 0.05 $\mathrm{mm} / \mathrm{rev}$ and a depth of cut of $0.1 \mathrm{~mm}$. Fig. 4 shows the influence of the cutting speed on the tool wear. There is little influence of the cutting speed on the tool wear within the range of cutting speed from $0.5 \mathrm{~m} / \mathrm{s}$ to $1.0 \mathrm{~m} / \mathrm{s}$. So, SEM observation and EDS analysis was carried out on the worn surface.

Fig. 5 shows the tool wear in the case of a cutting speed of $0.50 \mathrm{~m} / \mathrm{s}$. Fig. 5 (a) and (b) shows the SEM observation and Fig. 5 (c) shows the EDS analysis. Fig. 5 (b) shows the details of A shown in Fig. 5 (a). Fig. 5 (c) shows the EDS analysis in the case of the oxygen $(\mathrm{O})$ mapping on the cutting part shown

in Fig. 5 (a). First, as compared with the tool wear of the cutting speed $1.00 \mathrm{~m} / \mathrm{s}$ shown in Fig. 1 (b) and that of the cutting speed $0.50 \mathrm{~m} / \mathrm{s}$ shown in Fig. 5 (a), the tool wear of the cutting speed $0.50 \mathrm{~m} / \mathrm{s}$ shows the same characteristics as that of the cutting speed $1.00 \mathrm{~m} / \mathrm{s}$. Next, as compared with the worn surface of the cutting speed $1.00 \mathrm{~m} / \mathrm{s}$ indicated by " $B$ " shown in Fig. 3 (ii)(a) and that of the cutting speed of 0.50 $\mathrm{m} / \mathrm{s}$ indicated by " $\mathrm{B}$ " shown in Fig. 5 (b), many striae scratched by any hard material are remarkably found on the worn surface in the case of both the cutting speed $1.00 \mathrm{~m} / \mathrm{s}$ and the $0.50 \mathrm{~m} / \mathrm{s}$. Therefore, the main wear mechanism of the cutting speed $1.00 \mathrm{~m} / \mathrm{s}$ and the $0.50 \mathrm{~m} / \mathrm{s}$ is considered to be abrasive wear. Finally, as compared with the oxygen element on the worn surface of the cutting speed $1.00 \mathrm{~m} / \mathrm{s}$ shown in Fig. 3 (ii)(b) and that of the $0.50 \mathrm{~m} / \mathrm{s}$ shown in Fig. 5 (c), the oxygen mapping on the cutting part shown in the cutting speed $0.50 \mathrm{~m} / \mathrm{s}$ shows the same characteristics as that of the cutting speed $1.00 \mathrm{~m} / \mathrm{s}$. Therefore, the cutting speed is considered to have little influence on the cutting temperature within the range of the cutting speed from $0.50 \mathrm{~m} / \mathrm{s}$ to 1.00 $\mathrm{m} / \mathrm{s}$.
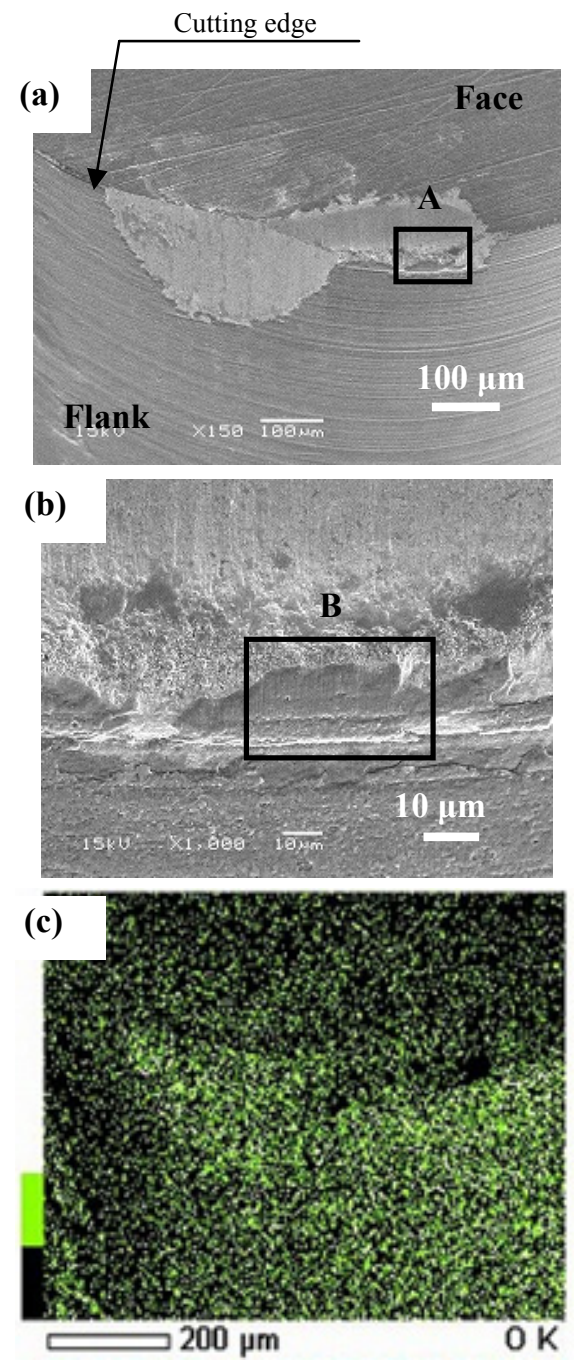

Fig. 5. SEM observation and EDS mapping analysis on the worn surface of (Al, Cr)N coated tool at cutting speed of $0.50 \mathrm{~m} / \mathrm{s}$. (a) SEM observation of cutting part, (b) details of A shown in Figs. (a), and (c) EDS analysis of oxygen mapping shown in Fig. (a).

As mentioned above the cutting speed is considered to have little influence on the tool wear within the range of the cutting speed from $0.50 \mathrm{~m} / \mathrm{s}$ to $1.00 \mathrm{~m} / \mathrm{s}$. 


\section{CONCLUSIONS}

In this study, to clarify the effectiveness of aluminum-chromium coating film for cutting hardened sintered steels, tool wear was experimentally investigated. The hardened sintered steel was turned with an aluminum-chromium based coated tool according to a physical vapor deposition (PVD) method. Moreover, the tool wear of the aluminum-chromium based coated item was compared with that of the ( $\mathrm{Ti}, \mathrm{Al}) \mathrm{N}$ coated tools.

The main results obtained are as follows:

1) The wear progress of the $(\mathrm{Al}, \mathrm{Cr}) \mathrm{N}$ coated cemented carbide tool was slower than that of the $(\mathrm{Ti}, \mathrm{Al}) \mathrm{N}$ coated cemented carbide tool.

2) Because the $(\mathrm{Al}, \mathrm{Cr}) \mathrm{N}$ coating film exhibited both higher hardness and higher oxidation temperature, the wear progress of the $(\mathrm{Al}, \mathrm{Cr}) \mathrm{N}$ coated cemented carbide became slower.

3) In addition, because the cutting temperature becomes lower due to the lower coefficient of friction of the $(\mathrm{Al}, \mathrm{Cr}) \mathrm{N}$ coating film, the wear progress of the $(\mathrm{Al}, \mathrm{Cr}) \mathrm{N}$ coated cemented carbide became slower.

4) In cutting hardened sintered steel with a (Al,Cr)N coated cemented carbide tool, there was little influence of the cutting speed on the tool wear within the range of the cutting speed from $0.50 \mathrm{~m} / \mathrm{s}$ to 1.00 $\mathrm{m} / \mathrm{s}$.

As mentioned above, it was clear that the $(\mathrm{Al}, \mathrm{Cr}) \mathrm{N}$ coated cemented carbide is an effective tool material in cutting hardened sintered steel.

\section{REFERENCES}

[1] JSPE, Handbook of Precision Machining, Tokyo, CORONA PUBLISHING CO., LTD., 1992, pp. 139 (in Japanese).

[2] T. Wada, K. Hiro, J. Fujiwara, and S. Hanasaki, "Machinability of hardened sintered steel," in Proc. the Seventh International Conference on Progress of Machining Technology, Ed. W. Y. Chen, Y. Yamane, R. Fan, and A. Ochu, 2004, pp.74-79.

[3] Y. Amada, T. Aoki et al., "Cutting performance of coated cemented carbide tools for hard work materials," Trans of JSME, Series C, 1994, vol. 60 , no. 577 , pp.2906-2910.

[4] S. Hanasaki, J. Fujiwara, T. Wada, and K. Hiro, "Tool wear of PVD coated cemnted carbide tool in turning of forged sintered material," " in Proc. the 5th International Conference on Progress of Machining Technology, Ed. D. C. Chen, N. Narutaki, Y. Yamane, W. Y. Chen, and A. Ochu, 2000, pp.42-47.

[5] T. Wada, K. Iwamoto, H. Hanyu, and K. Kawase, "Tool wear of $(\mathrm{Al}, \mathrm{Cr}) \mathrm{N}$ coated cemented carbide in cutting sintered steel," Journal of the Japan Society of Powder and Powder Metallurgy, vol. 58, pp.459-462, 2011.

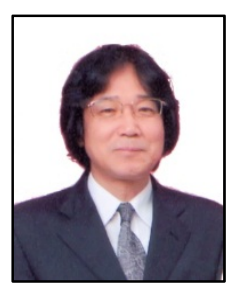

Tadahiro Wada received the B.S. degree in engineering in 1978 from Kanazawa University and the M.A. degree in engineering in 1980 from Osaka University in Japan. He got the Ph.D in engineering in 1986 from Osaka University.

$\mathrm{He}$ is now a professor at Precision Laboratory in the Mechanical Engineering of Nara National College of Technology. Field of his research is the Manufacturing Engineering, Surface Modification and Machining Performance. 